\title{
VISÕES DO IMPÉRIO: A VISUALIDADE DA ÁFRICA COLONIAL NA LITERATURA DE H. RIDER HAGGARD
}

\author{
VISIONS OF EMPIRE: THE VISUALITY OF COLONIAL AFRICA IN \\ H. RIDER HAGGARD'S LITERATURE
}

Evander Ruthieri da Silval

RESUMO: Na chamada Era dos Impérios do século XIX, os romances de H. Rider Haggard (1856-1925) alcançaram expressividade no mercado editorial, e, ao enredarem tramas ambientadas nos territórios sul-africanos, informavam a imaginação de muitos dos seus leitores e leitoras acerca da ocupação de outros territórios, dos encontros interétnicos e interculturais tramados nas fronteiras geopolíticas dos interesses coloniais. Este artigo concentra-se na visualidade da África colonial em dois romances de Rider Haggard, Swallow (1899) e The Ghost Kings (1908). A ênfase da análise recai sobre as imagens e ilustrações que acompanhavam estes romances, compreendendo-as como elementos associados à dimensão política da ficcionalidade, em especial os códigos visuais que se entrecruzam aos imaginários e estereótipos relacionados aos territórios sul-africanos.

PALAVRAS-CHAVE: História e Literatura; História da África; H. Rider Haggard.

ABSTRACT: In the so-called Age of Empires of the Nineteenth century, H. Rider Haggard's novels and romances became best sellers in the publishing market, and with plots set in southern Africa, they informed the imagination of many of their readers about the occupation of other territories, and inter-ethnic and intercultural encounters in the geopolitical frontiers of colonial interests. This article concentrates on the visuality of colonial Africa in two romances by Rider Haggard, Swallow (1899) and The Ghost Kings (1908). The analysis rests on the images and illustrations that accompanied these books, understanding them as elements associated with the political dimension of fictionality, especially the visual codes that intersect the imaginary and stereotypes associated with the South African territories.

* O presente trabalho foi realizado com apoio da Coordenação de Aperfeiçoamento de Pessoal de Nível Superior - Brasil (CAPES).

${ }^{1}$ Doutor em História pela Universidade Federal do Paraná, com período sanduíche na University of Exeter (Reino Unido). Bolsista da Coordenação de Aperfeiçoamento de Pessoal de Nível Superior. Atualmente, professor colaborador no Departamento de História da Universidade Estadual de Ponta Grossa. 
KEYWORDS: History and Literature; History of Africa; H. Rider Haggard.

As relações entre História e ficções literárias têm instigado parte da produção historiográfica recente, com ênfase em análises que se detém em torno das condições sociais, políticas e culturais dos sujeitos históricos constituintes do universo de produção intelectual. Ademais, o cerne dessa proposição teórico-metodológica, que se atenta às redes de interlocução social e intertextual da literatura, compreende os textos enquanto objetos culturais e elementos estruturantes das experiências cotidianas, portanto, inseridos em movimentos da sociedade e de seu tempo, e, por esse motivo, fontes inesgotáveis de substratos para a inquirição das vivências humanas, entre razões e sensibilidades, no tempo pretérito.

Pelo menos desde a década de 1980, alguns pesquisadores tem se preocupado com a historicidade da dimensão gráfica e editorial dos livros, bem como sua materialidade, circulação e suporte, ao enfatizar a pertinência de elementos paratextuais e das formas materiais sobre a "produção de sentido e sobre as práticas de leitura" (ABREU, 2003: 13). Afinal, "nenhum texto existe fora do suporte que lhe confere legibilidade; qualquer compreensão de um texto, não importa de que tipo, depende das formas com as quais ele chega até seu leitor" (CHARTIER, 1992: 220). O estudo pormenorizado das ilustrações que integram as ficções literárias configura-se como uma possível chave de análise, considerando as imagens figurativas, "segundo as categorias e os preceitos de seu próprio tempo" (VENÂNCIO, 2006: 14), como objetos culturais dotados de esteticidade e visualidade, carregados de valores simbólicos e elementos políticos.

No que diz respeito aos textos e imagens veiculados durante a chamada "Era dos Impérios" (HOBSBAWM, 2014) da segunda metade do século XIX, a ênfase recai sobre as formas pelas quais estas produções culturais, difundidas no cotidiano de homens e mulheres nas metrópoles e nas colônias, convergiam na produção de imaginários sociais a respeito das práticas políticas coloniais. Nas últimas décadas do século XIX, o romance de aventura, estruturado a partir 
de certa sensibilidade romântica e pelo racialismo vulgarizado, informava o arcabouço imaginativo de muitos dos seus leitores a respeito dos territórios ultramarinos e de suas populações, frequentemente associando-as a estereótipos étnico-raciais que visavam legitimar a conquista colonial. Nas visões do Império Britânico, particularmente o papel das regiões coloniais, formuladas nestes romances, as regiões coloniais apareciam como espaços exóticos e periculosos, nos quais homens comuns, distantes das restrições morais e das convenções sociais das metrópoles, convertiam-se em heróis, aventureiros e descobridores. O romancista britânico H. Rider Haggard (1856-1925) adquiriu notoriedade no período em questão, pois, com base em sua experiência junto à administração colonial na África do Sul, produziu uma série de romances ambientados naquela região, nos quais expressava sentimentos e sensibilidades políticas ligadas à conquista de outros territórios e à subjugação das chamadas "raças inferiores".

$\mathrm{O}$ artigo concentra-se na análise e problematização da visualidade do projeto colonial britânico a partir das expressões gráficas, isto é, as ilustrações que acompanhavam os romances Swallow, A Tale of the Great Trek (1899) e The Ghost Kings (1908), ambientados na África do Sul da década de 1830. Em comum, estes romances aventurescos narravam os deslocamentos étnicos e os conflitos gerados a partir do chamado Great Trek (1835-1846), período de migrações internas dos bôeres rumo ao interior do subcontinente, e do mfecane (c. 1815-1835), termo associado ao expansionismo militar dos Zulus na mesma região. Os códigos visuais e os esquemas imagéticos, em incessante interação com as narrativas textuais, evidenciam a dimensão política das ficções literárias, ao idealizar certo senso de protagonismo colonial em torno dos personagens britânicos a partir da ênfase na suposta benevolência das ações engendradas nos processos de ocupação colonial.

\section{H. Rider Haggard e a África do Sul}


No que se refere ao lugar dos textos literários, mormente dos romances aventurescos, publicados no cerne dos encontros e embates coloniais do século XIX, a atenção especial da historiografia contemporânea ${ }^{2}$ tem recaído sobre as relações entre ficção e imaginários políticos na construção de referenciais textuais e imagéticos a respeito das colônias ultramarinas, sobretudo dos territórios sul-africanos, marcados por disputas territoriais entre as décadas de 1880 e 1900. No período em questão, os romances de H. Rider Haggard alcançaram expressividade no mercado editorial, pois, ao enredarem tramas ambientadas na África colonial, informavam a imaginação de muitos dos seus leitores acerca da ocupação política de outros territórios, dos encontros interétnicos e interculturais tramados nas fronteiras geopolíticas dos interesses coloniais. Muitos dos seus romances relacionavam-se com as leituras do passado no período, pois, ao narrarem as vicissitudes de personagens comuns, alçados ao heroísmo por suas ações individuais e qualidades redentoras, as tramas de Haggard selecionavam e enfatizavam episódios históricos que eram considerados por ele como representativos do processo de formação da unidade nacional sul-africana, justamente em um período no qual diversas medidas políticas malfadadas foram tomadas para garantir a concretização de uma confederação sul-africana.

Afinal, até 1910, o atual estado sul-africano encontrava-se dividido entre as Colônias britânicas do Cabo e de Natal, os protetorados e territórios nativos, e as repúblicas bôeres do Transvaal (Zuid-Afrikaansche Republiek, República Sul-Africana) e do Estado Livre de Orange (Oranje-Vrystaat). Os conflitos interétnicos ocasionados na região, sobretudo entre britânicos, bôeres e Zulus, bem como o acirramento de interesses econômicos derivados das descobertas de jazidas auríferas e diamantíferas nas décadas de 1870 e 1880, atraíram o foco

\footnotetext{
${ }^{2}$ Ver, por exemplo, BEGHETTO, Lorena. Aventura e alteridade: o domínio de outros territórios na literatura de aventura de Emilio Salgari (1862-1911). Tese de doutoramento em História. Curitiba: UFPR, 2014; BRANTLINGER, Patrick. Rule of Darkness: British Literature and Imperialism (1830-1914). Ithaca: Cornell University Press, 2013; BREPOHL, Marion. Imaginação literária e política: os alemães e o imperialismo. Uberlândia: EdUFU, 2010; GOMES, Raquel. Uma feminista na contramão do colonialismo: Olive Schreiner, literatura e a construção da nação sul-africana (1880-1902). São Paulo: Annablume, 2013; MARTINS, Leonor. Um Império de Papel: imagens do colonialismo português na imprensa periódica ilustrada (1875-1940). Lisboa: Edições 70, 2014.
} 
do público leitor na metrópole, e isto não apenas nas notícias veiculadas cotidianamente na imprensa periódica, mas também, e sobretudo, na literatura de aventura, romances repletos de cenários exóticos e episódios de bravura e coragem, os quais constituíam um gênero ficcional que galgou o status de bestselling no mercado editorial finissecular (RICHARDS, 1987). Estas produções literárias, remetendo-se à sensibilidade e ao domínio da significação simbólica, contribuíram para a formação de estereótipos que caracterizavam a África como o "continente negro", espaço de seres exóticos e violentos, ou de terras inóspitas e inabitadas; simultaneamente, a seleção de personagens e episódios históricos que transparecem em plano de fundo de muitos dos romances aventurescos produzidos naquele período reimaginavam a formação dos estados coloniais, ao exemplo da África do Sul, que passou a ser alvo de perscruto de diversos romancistas, tais como George Alfred Henty, Bertram Mitford, Robert Michael Ballantyne e H. Rider Haggard.

O caso do literato Henry Rider Haggard reveste-se com relevância no objetivo de pensar as relações entre literatura e práticas políticas coloniais ao final do século XIX. Isto porque, além de ter atuado na administração da Colônia de Natal e no Transvaal durante a sua juventude, parte expressiva da produção literária de Haggard encontra-se ambientada no continente africano. Trata-se de romances, ao exemplo de King Solomon's Mines (1885) e She, a History of Adventure (1886), repletos de cenários de aventura em contextos fortemente homossociais, os quais reimaginam a África como um lugar de revitalização da virilidade, de triunfos econômicos e políticos, espaços em que, destituídos das limitações sociais e das restrições morais dos centros urbanos, homens comuns convertiam-se em heróis bravos e valentes. Estes textos literários são igualmente estruturados a partir das vivências de Haggard na África, de modo que, entrecruzada à presença de aventureiros europeus, suas páginas encontram-se abarrotadas de personagens africanos, sobretudo os Zulus, cuja representação oscila entre a admiração e o anátema, entre a crença no imperialismo enquanto inexorável força civilizatória e o lamento pelo 
esfacelamento de práticas culturais que, em sua perspectiva, eram inerentes à organização social africana.

Estas produções literárias associavam-se ao recrudescimento das práticas políticas coloniais entre as décadas de 1870 e 1890 , e desencadearam em uma nova semântica em torno da ideia de aventura e da figura do aventureiro. No século XVIII, o aventureiro era visto como um personagem nas margens da legalidade, um criminoso ou usurpador estigmatizado, que convocava certa figura de errância, mas que se acomodava adequadamente ao espaço europeu da época. Contudo, a imagem do aventureiro que domina a ficção na metade do século XIX tornava-se capaz de romper com o espaço europeu: longe de ser uma figura intrusa no espaço cotidiano, o aventureiro se torna uma figura de partida, cuja representação evocava a idealização de distâncias geográficas, de modo que as constantes referências a mapas tornavam-se explicitamente um vetor do imaginário da aventura. Segundo Sylvain Venayre, a definição de aventura no século XIX trouxe consigo uma série de valores difundidos na época: a exaltação do individualismo e da iniciativa individual; a valorização da conquista e do risco mortal, vistos como uma forma de viver intensamente; e certa virilização da aventura, na medida em que esta era entendida como "um meio de se tornar homem, e um homem rigoroso" (VENAYRE, 2001: 93-112). Estas figurações literárias contribuíam para a legitimação pública de violências concretas derivadas das práticas coloniais, convertendo o processo de ocupação da África em tramas românticas que visavam proporcionar o deleite e o engajamento afetivo de leitores comuns. Neste contexto, a aventura estava enlaçada às sensibilidades políticas, "as emoções e os sentimentos coletivos" que dão "sustentação às práticas políticas particulares" (ANSART, 2019: 8), na medida em que visava promover a conquista colonial, apresentada como resultante das ações de homens fortes e joviais, movidos pelo espírito empreendedor e aventuresco.

Homens como Rider Haggard, que, ao deixarem as rígidas convenções sociais nas metrópoles, partiam para as colônias em busca de enriquecimento e ascensão social: afinal, a trajetória intelectual do romancista sofreu uma 
inflexão significativa em 1875, quando, aos dezenove anos, foi enviado por sua família para a Colônia de Natal, na África do Sul, onde ocuparia um cargo nãocomissionado na administração colonial do governador Henry Bulwer. Dois anos depois, Haggard passou a integrar a equipe de Theophilus Shepstone, responsável pela anexação da república bôer do Transvaal às posses britânicas, ação que eventualmente desencadearia a guerra Anglo-Bôer de 1880-1881 e a devolução do território transvaalense. A inserção de Haggard no serviço burocrático colonial catapultaria o jovem à elite branca nas colônias sulafricanas, e colocá-lo-ia em contato direto com a instável situação política na região ao sul do Rio Zambezi, demarcada, ao final da década de 1870, por uma intensificação de conflitos, sobretudo com os Zulus, liderados por Cetshwayo. Amargurado com a "perda" do Transvaal, Haggard deixou a África do Sul em meados de 1881 e retornou à metrópole onde, nos anos seguintes, utilizou de sua experiência colonial para redigir romances aventurescos e sentimentais ambientados na África (SILVA, 2018).

A produção literária de Rider Haggard encontra-se perpassada por ambiguidades políticas, sintomáticas das relações entre o letrado e a manutenção dos territórios coloniais: por um lado, crê fervorosamente na expansão colonial, interpretando-a como uma força positiva capaz de disseminar justiça e paz entre as chamadas "raças inferiores"; por outro lado, compreende o aspecto destrutivo do imperialismo, categorizando-o como um elemento desestabilizador de formas africanas de organização social e cultural, em especial entre os Zulus, que considera como exemplos de beleza viril e bravura selvagem. Soma-se ainda o peso do racialismo e dos preconceitos raciais a partir dos quais Haggard constrói seus personagens e suas narrativas, frequentemente associando comportamentos aberrantes à mestiçagem e relacionando as populações negras na África do Sul, especialmente os Zulus, a extremos de heroísmo e bravura, ou periculosidade e degenerescência. Por toda a sua insídia e perniciosidade, o discurso racial desempenhava um papel chave nos paradigmas de inclusão e exclusão das políticas coloniais, tanto nas colônias do Cabo e de Natal, quanto nas repúblicas bôeres do Transvaal e do 
Estado Livre de Orange, onde, legislações excludentes e segregacionistas visavam, a partir da segunda metade do século XIX, restringir o acesso a direitos políticos e civis às populações negras.

Estes elementos integram, em maior ou menor medida, as tramas de Swallow e The Ghost Kings, romances ambientados no interior do subcontinente sul-africano na década de 1830. Nestas obras, Haggard sobrepõe os dramas de personagens comuns a um plano de fundo histórico: o Great Trek, período de migrações dos bôeres voortrekkers, descendentes de holandeses e huguenotes franceses, que, ao deixarem a Colônia do Cabo rumo ao interior, visavam escapar da esfera de influência política britânica na região. Direta ou indiretamente, os romances de Haggard igualmente relacionavam os percalços de seus protagonistas ao que a historiografia sul-africana denominou posteriormente de mfecane, processos históricos de deslocamentos populacionais e migrações internas relacionadas por historiadores coloniais do final do século XIX ao expansionismo militar dos Zulus liderados por Shaka kaSenzangakhona (1787-1828). Na década de 1870, período de tensões políticas e militares entre britânicos e Zulus, diversos historiadores coloniais, ao exemplo de George McCall Theal, formularam uma perspectiva do mfecane que responsabilizava o Reino Zulu por genocídios étnicos e esvaziamentos territoriais no decênio de 1830 , circunstância que teria possibilitado a ocupação daqueles territórios por britânicos e bôeres rumo ao interior das colônias (RICHNER, 2005).

Swallow, a tale of the Great Trek, publicado originalmente em formato folhetinesco no impresso The Graphic entre julho e outubro de 1898, e em tomo único no ano seguinte, apropria-se destes elementos históricos para narrar as trajetórias de três personagens centrais: a jovem bôer Suzanne Botmar, seu noivo, o expatriado anglo-escocês Ralph Kenzie e a curandeira africana Sihamba Ngenyanga. Em Swallow, Haggard constrói uma narrativa de perigo sexual e ameaça racial, ao apresentar o vilão Piet van Vooren, filho de um fazendeiro bôer e de uma africana, e que almeja raptar Suzanne para seu harém de esposas africanas. As ações vilanescas de Piet van Vooren são contrapostas à 
bravura de Ralph, que passa dois anos em busca de sua noiva desaparecida, e da africana Sihamba, que abriga e protege Suzanne em seu kraal. No desfecho da trama, Sihamba sacrifica-se para salvar Suzanne, a qual é resgatada por Ralph e escapa do ataque de um impi $^{3}$ Zulu. Em retratos de papel e letras, Haggard visou narrar os sentimentos dos trekkers que, ao deixarem suas terras na metade os anos de 1830, lançavam-se a uma vida de martírios e incertezas no interior do subcontinente e, neste processo, delineia o Great Trek enquanto um mito fundacional de origem nacional, protagonizado por ações conjuntas de bôeres e britânicos.

$\mathrm{Na}$ época da publicação, a constituição de narrativas históricas a respeito da formação nacional e ocupação territorial da África do Sul associava-se a um período de particular instabilidade política e falência de projetos que, emanados de distintos grupos sociais ou posicionamentos políticos envolvidos nestes processos históricos, almejaram o estabelecimento de uma confederação capaz de unir ou unificar os territórios no subcontinente sul-africano. Parte destas narrativas do passado sul-africano se voltava ao período do Great Trek da década de 1830, a "grande jornada" dos bôeres, processo considerado, em particular pelos emergentes movimentos nacionalistas afrikaners, como mito de origem de uma África do Sul branca. Estes relatos, produzidos tanto por historiadores coloniais quanto por literatos no último quartel do século XIX, visavam promover sentidos explicativos para a contemporaneidade geopolítica sul-africana, a partir de um olhar voltado ao passado, entre a memória coletiva e a imaginação histórica, no escopo de engendrar representações identitárias estruturadas a partir de sentimentos de pertencimento ou paradigmas de exclusão (SCHREUDER, 1986: 95-158). Desta forma, Swallow, que foi escrito um período de particular instabilidade e animosidades bélicas entre os britânicos e bôeres, sobretudo após o malfadado Jameson Raid - operação militar promovida por Leander Starr Jameson e Cecil Rhodes com a intenção de anexar o Transvaal às posses britânicas em 1895 - e a eclosão da guerra sul-

\footnotetext{
${ }^{3}$ O termo impi (ou iziMpi no plural) é utilizado para designar os regimentos militares Zulus, sobretudo no contexto oitocentista (LABAND, 2009: 328).
} 
africana em 1899, enredava uma origem étnica e nacional para a África do Sul a partir da união harmoniosa entre elementos bôeres (Suzanne) e britânicos (Ralph), com o amparo benevolente de populações negras (Sihamba).

A serialização de The Ghost Kings ocorre entre outubro de 1907 e junho de 1908, na revista londrina Pearson's Magazine, seguido pela primeira edição no segundo semestre de 1908. Ambientado na Pondolândia, na Zululândia e, muito possivelmente, na atual Botswana, o romance concentra-se na história de Rachel Dove e Richard Darrien, dois jovens de origem britânica que se apaixonam em meio aos eventos associados à mfecane. Rachel, filha de um missionário britânico, é requisitada pelos Zulus devido à suposta relação com Inkosazana, um espírito poderoso associado às tempestades. Por este motivo, Rachel é raptada por Dingane, o inkosi (rei, chefe) Zulu, e levada até seu kraal. Simultaneamente, o vilanesco Ishmael, um britânico que assimilou costumes nativos e vivia por anos entre africanos, tenta forçar a jovem a casar-se com ele. Rachel é amparada e protegida por Noie, uma mulher africana, descendente do "povo fantasma", uma civilização dotada de poderes sobrenaturais, e que vive ao norte da Zululândia. Na parte final da trama, Rachel e Noie partem ao norte, e impedem o corrupto e ambicioso Eddo de tomar o poder do "povo fantasma", embora à custa do sacrifício da jovem africana e de toda a sua raça "fantasma".

A relação entre Rachel e Noie, baseada na benevolência e na obediência voluntária, relaciona-se ao que foi categorizado por Sarah Clark como exemplos de uma "colonização filantrópica" nos romances de Rider Haggard produzidos a partir do final da década de 1890: a caridade e a benevolência vistas como virtudes estruturantes de relações de poder capazes de moldar as populações nativas em sujeitos colonizados. No mesmo período em que escreveu The Ghost Kings, Haggard encontrava-se engajado com diversas propostas de reformas sociais e agrícolas como solução para as crises na produção agrícola que afetavam a Inglaterra desde a década de 1870; para ele, a crise seria resolvida a partir do esforço conjunto de investimentos públicos e sociedades beneficentes, ao exemplo do Salvation Army. Para Haggard, a salvação do Império Britânico seria conduzida por uma classe de indivíduos 
ligados a atividades agrícolas em âmbito transnacional, por meio de esforços filantrópicos capazes de reeducar e civilizar as chamadas "raças inferiores": em The Ghost Kings, a questão fica ilustrada pela virtuosa Rachel Dove, cuja benevolência tornava-se capaz de salvar o homem que amava e proteger uma linhagem africana das forças ameaçadoras de seus membros corruptos (CLARK, 2017).

Os romances de Haggard, tanto nas versões serializadas na imprensa periódica quanto nas edições em tomo único, encontravam-se amparada em recursos visuais, sobretudo ilustrações de Maurice Greiffenhagen, William Hatherell e Arthur Michael. As imagens figurativas, somados às narrativas textuais, integravam a cultura visual do fin-de-siècle e, ademais, informavam o arcabouço imaginativo de muitos dos seus leitores e leitoras na metrópole a respeito da expansão colonial. Sensibilidade política, cultura visual e literária encontram-se articuladas nestas páginas, as quais fornecem elementos para o estudo crítico dos "sistemas simbólicos em que assenta e através do qual opera o imaginário social”, os quais são "construídos a partir da experiência dos agentes sociais, mas também a partir dos seus desejos, aspirações e motivações" (BACZKO, 1985: 311). Este ponto de partida incide sobre o objetivo central do artigo, a saber, a análise da visualidade da África colonial nos dois romances de Rider Haggard, Swallow e The Ghost Kings. A ênfase metodológica recai sobre cotejo e as interlocuções entre imagens figurativas e textualidade nas obras elencadas, compreendendo-os como elementos associados à dimensão política da ficcionalidade, em especial, os códigos visuais que se entrecruzam à percepção dos territórios coloniais e os esforços de conferir certa áurea de legitimidade aos projetos colonialistas.

\section{A visualidade da África colonial}

Na primeira metade do século XIX, a circulação de imagens sobre a África e os africanos na Europa derivava em parte dos panfletos produzidos pelas campanhas abolicionistas, as quais, edulcoradas por certa sensibilidade 
romântica e em tom de denúncia, apresentavam vasto leque de violências associadas ao tráfico de escravizados; ou, ainda, nos relatos de missionários e de viajantes, que retratavam os africanos como vítimas das atrocidades coloniais ou mesmo enquanto curiosidades etnográficas. Sob muitos aspectos, esta tradição visual era herdeira das discussões filosófico-científicas que, ao longo do século XVIII, visavam demarcar as diferenças físicas, morais e intelectuais entre negros e brancos, usualmente caracterizadas em termos hierárquicos (CURRAN, 2013). A intensificação das práticas políticas coloniais a partir da década de 1860, a "partilha da África", a exploração de mão-de-obra africana e de recursos naturais e, sobretudo, a proliferação de teorias de cunho racialista - hoje tidas como pseudocientíficas - ressignificaram as representações textuais e imagéticas dos africanos nas publicações europeias: a antropologia evolucionista sugeria que as populações africanas eram pertencentes a uma diferente espécie, a um ponto fixo e retrógrado na escala evolutiva, e portanto inferiores às raças anglo-saxônicas (BRANTLINGER, 1985). Ao fin-de-siècle, um verdadeiro arsenal imagético difundia o "racismo mercantil e a propaganda imperial (...), imprimindo imagens da conquista colonial em caixas de sabão, caixas de fósforo, latas de biscoito, garrafas de uísque, latas de chá e barras de chocolate" (MCCLINTOCK, 2010: 309).

Conforme tratou Naiara Krachenski Stadler em seus estudos sobre a visualidade da propaganda neocolonial alemã em fins do século XIX, o entrecruzamento de textos e imagens nestas produções culturais incidia na produção de imaginários a respeito da África colonial, com ênfase na ideia de "missão civilizacional" associada ao colonialismo. Segundo a autora, há um padrão nestas produções coloniais, mediante o qual o negro africano era frequentemente associado à lógica racial da rebeldia ou da passividade, postulando que precisa "ser dominado e subjugado, seja porque é 'naturalmente' dado à dominação, seja porque é bárbaro e precisa ser controlado" (STADLER, 2015: 87). Segundo Anne MacClintock, muitas destas representações visuais das colônias e de seus habitantes eram difundidas no espaço doméstico metropolitano por um fluxo infindável de mercadorias, tais 
como produtos de limpeza e higiene pessoal, os quais, com certa frequência, associavam a negritude à sujeira, com o fito de "legitimar a violenta imposição os valores culturais e econômicos dos imperialistas, com a intenção de purificar e, assim, subjugar o ‘sujo' corpo africano” (MCCLINTOCK, 2010: 333).

A circulação destas imagens figurativas sobre as colônias ocorria também pelas expressões gráficas constituintes da literatura de aventura e entretenimento popularizada no período, em especial nas ilustrações que retratavam as sagas ficcionais de homens e mulheres em África. Com certa frequência, estes elementos visuais enfatizavam a natureza exótica ou inóspita da África subsaariana, de suas riquezas naturais e da necessidade de cercear e controlar a mão-de-obra africana sob pretextos civilizatórios. Simultaneamente, reforçavam determinados estereótipos raciais em torno das populações negras africanas, representando-as tanto como rebeldes e periculosas, ou como exóticas e subservientes, destituídas de capacidade para ação própria. Para muitos dos seus leitores e leitoras na metrópole, estas representações textuais e imagéticas atuavam como cartilhas do colonialismo, apresentando os territórios coloniais como espaços de risco ou de infindáveis oportunidades econômicas e políticas. Os romances aventurescos, mormente voltados a um público infantojuvenil e repletos de tesouros perdidos e civilizações majestosas na África, apresentavam o colonialismo como possibilidade de enriquecimento imediato, sobretudo após a descoberta das minas de ouro e diamantes na África do Sul na década de 1870.

Além dos folhetins ilustrados, diversas revistas contribuíam com a formação do arcabouço imaginativo de muitos dos seus leitores e leituras a respeito do colonialismo e da ocupação geopolítica da África pelos europeus. Tome-se, a título de exemplo, a Pearson's Magazine, fundada em 1896 pelo "magnata das comunicações" Arthur Pearson: desde seus primeiros volumes, a revista expressava um vasto entusiasmo em fornecer informações a respeito das colônias e de seus habitantes. Os volumes publicados no primeiro biênio de existência da revista incluíam artigos sobre as jazidas diamantíferas na África do Sul, a mobilização de soldados nativos na Índia, as estratégias militares de 
manutenção das fronteiras europeias e a ação de capitães britânicos no Transvaal (CLARKE, 2014). Amplamente ilustrado, o primeiro volume da Pearson's apresentava ao seu público leitor a saga do soldado anglo-irlandês William Beresford durante a Guerra Anglo-Zulu, com descrições sanguinolentas da ação militar de britânicos nos conflitos; o texto deu início à coluna "Um dos feitos mais bravos que já vi", recorrente nos volumes seguintes, e que, por meio de relatos testemunhais, apresentava episódios de companheirismo, bravura e coragem no embate colonial, valores associados à masculinidade dos comandantes e soldados britânicos nos conflitos sulafricanos.

Outros impressos, ao exemplo do jornal ilustrado The Graphic, em circulação desde 1869, apresentavam aos seus leitores, entre publicidades, colunas sociais e folhetins, gravuras e fotografias que representavam as colônias como espaços exóticos, de modo a promover constantes interações entre o público leitor e os embates coloniais. A problematização e a interpretação histórica do arsenal imagético ligado à visualidade do colonialismo britânico envolvem uma atenção redobrada à simbologia destes elementos evocados pela articulação entre política colonial e literatura aventuresca nas representações da ocupação do território sul-africano na década de 1830. Assim, uma possibilidade de análise do corpus documental, formado pelas ilustrações que integram os romances de Haggard, Swallow e The Ghost Kings, encontra-se nas dimensões da "intericonicidade", uma versão visual do dialogismo bakhtiniano, centrada no "processo de produtividade de uma imagem que se constrói como absorção ou transformação de outras imagens" (ARBEX, 2003: 6). Enquanto o dialogismo remete-se às relações de sentidos construídos na interação entre enunciados, a intericonicidade referencia as relações dialógicas entre imagens (ou, ainda, entre imagens e textos). Trata-se, portanto, de pensar as repetições, apropriações e ressignificações de elementos figurativos em circunstâncias históricas que incidem sobre a produção de narrativas a respeito da ocupação colonial, em especial, nos territórios sulafricanos. 
Ao ser publicado em formato folhetinesco, Swallow esteve acompanhada por ilustrações produzidas pelo aquarelista William Hatherell. Posteriormente, quando publicada em tomo único, os editores acrescentaram quatro ilustrações de autoria de Maurice Greiffenhagen, colaborador frequente nos livros de Rider Haggard. As ilustrações de Hatherell mobilizam códigos visuais que, ao retratar as populações africanas, prezam pela ausência de pluralidade nos traços e personagens. Um exemplo disso encontra-se na gravura (figura 1) que marcava a abertura do Capítulo XXI, "The Vision of Ralph and Suzanne", e que apresenta a heroína Suzanne sendo aclamada e reconhecida pelos guerreiros liderados pelo chefe Sigwe. A imagem endossa o contraste entre a negritude dos soldados africanos, quase imperceptíveis na multidão, e a brancura da jovem bôer, investindo-a enquanto uma fonte de reverência colonial. O empoderamento simbólico de Suzanne, entre a imagética e a textualidade, desempenha um evidente papel político, pois assegura a manutenção da autoridade europeia sobre as populações negras, mesmo que sob pretextos justos ou benevolentes, sintomáticos dos argumentos sustentados por muitos intelectuais engajados com a expansão das colônias na África do Sul e que enfatizavam determinados valores que consideravam como positivos no colonialismo: o "fardo do homem branco" e a "missão civilizadora" com as chamadas "raças inferiores". 
Figura 1

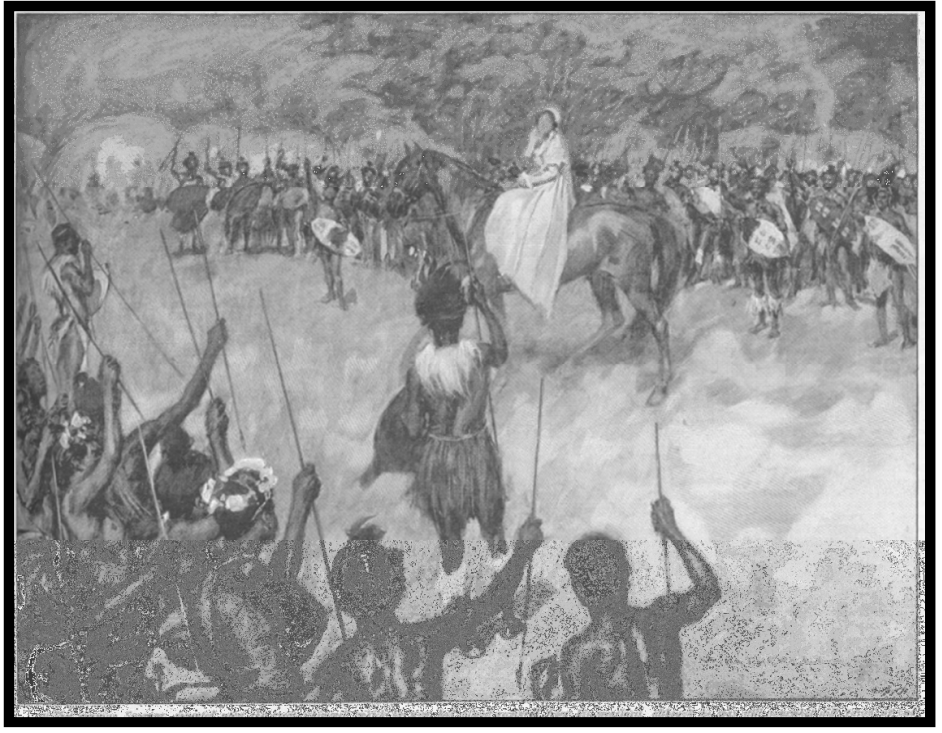

Fonte: Swallow, a tale of the Great Trek. The Graphic, 10 de setembro de 1898, p.345.

Tanto em Swallow, quanto em The Ghost Kings, a bondade era apresentada como um sentimento definidor de "subjetividades consideradas femininas, associadas ao amplo terreno moral dos cuidados" (MARTINS, 2013: 144). Suzanne e Rachel, ao salvarem as vidas de Sihamba e Noie, respectivamente, eram vistas como portadoras de "virtudes regeneradoras da ordem moral e social" (MARTINS, 2013: 144). Contudo, a despeito destas demonstrações de bondade e solidariedade, o Great Trek era retratado pelos ilustradores de Haggard como um período de intensa violência. Enquanto Haggard, por meio da textualidade, enfatiza sentimentos como nostalgia e melancolia como parte da experiência dos voortrekkers, a imagem de abertura (figura 2) destaca a violência do período, ao apresentar a mãe de Suzanne, Vrow Botmar, atacando um guerreiro Ndebele com machadadas, enquanto que, aos fundos, seus compatriotas bôeres combatem o avanço inimigo com armas de fogo. A partir da "confrontação entre os códigos e convenções da representação figurada e os traços outros de um sistema de percepção próprios a uma época dada" (VENÂNCIO, 2006: 14), percebe-se que a ilustração reforça a associação entre a força feminina e a manutenção da autoridade colonial, mas, publicada justamente num período de acirramento das tensões entre britânicos e 
bôeres nas vésperas da guerra sul-africana, relacionava estes últimos à intensificação da violência no contexto do Great Trek.

\section{Figura 2}

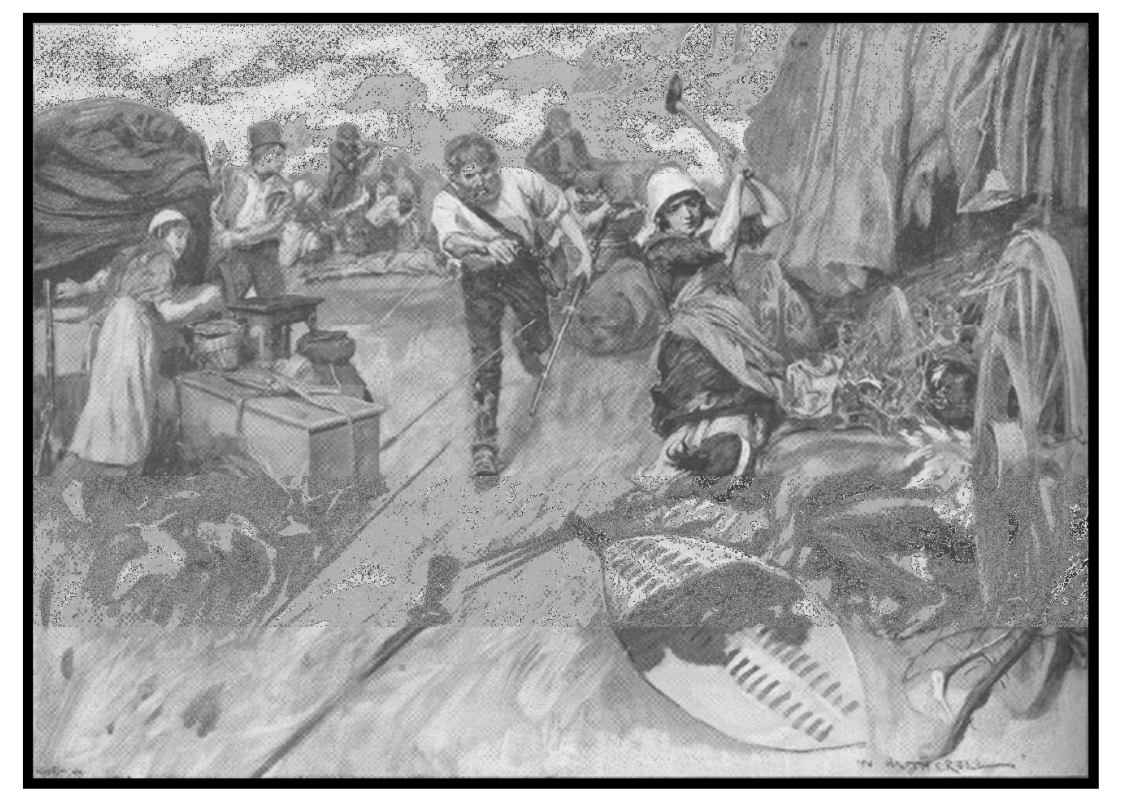

Fonte: Swallow, a tale of the Great Trek. The Graphic, 01 de outubro de 1898, p.405

Em Swallow, Haggard apresenta os conflitos gerados entre o contato dos bôeres com os Ndebele e os Zulus, em um período de intensos deslocamentos populacionais e disputas territoriais. No episódio em questão, que representava o confronto entre os Ndebele e os bôeres em Vechktop (outubro de 1836), Haggard e seus ilustradores remetiam seus leitores, direta ou indiretamente, a uma questão que recentemente foi retomada pela historiografia concernente à África do Sul da metade da década de 1830: os conflitos entre os trekkers e os Ndebele provocaram profundas e decisivas transformações nas relações políticas e no controle das terras entre os rios Orange e Limpopo. Por cerca de uma década, Mzilikazi, o inkosi dos Ndebele, havia controlado as planícies, e a incessante movimentação de seus regimentos amabutho garantiam a fidelidade das lideranças nos reinos subordinados e a possibilidade de capturar gado de grupos rivais em uma esfera de influência que se estendia por centenas de quilômetros para além do cerne do reino. As estratégias seguidas pelo inkosi 
garantiam que parte desses territórios permanecesse virtualmente inutilizável, exceto por grupos que não tivessem gado a perder, ao exemplo dos Tswana. Em sua área de influência política, Mzilikazi não permitiria chefes independentes, forçando muitos deles a migrar para outras regiões. A batalha de Vechktop transformou esse equilíbrio político, ao demonstrar que um laager adequadamente defendido poderia resistir aos ataques de um amabutho. Mzilikazi, compreendendo o risco e a possibilidade de ataques de reinos inimigos, voltou suas energias a proteger seus rebanhos e cessou as incursões militares contra os trekkers, deslocando-se posteriormente rumo ao território conhecido como Matabelelândia (ETHERINGTON, 2013).

Simultaneamente, outras imagens no romance concatenam uma série de estereótipos raciais difundidos no período a respeito dos Zulus: no início do século XIX, as lideranças Zulus, ao exemplo de Shaka e Dingane, eram representados como combativos e sanguinolentos, mas vistos pelos europeus como ameaças maiores às populações africanas do que à presença europeia na região; por isso, na iconografia das décadas de 1830 e 1840, os Zulus eram retratados como curiosidades etnográficas, e não necessariamente como inimigos do Império Britânico. Contudo, o acirramento das tensões a partir as décadas de 1860 e 1870, que culminaram na Guerra Anglo-Zulu de 1879, e o desenvolvimento de teorias consideradas hoje como pseudocientíficas a respeito da variação racial, resultaram em acepções polissêmicas sobre os Zulus: alguns os distinguiam dos demais africanos, localizando suas origens no nordeste africano para enfatizar seu processo de degenerescência ao deslocarem-se para o sul; outros circunscreviam os Zulus a uma racialidade atrofiada e degenerada, de modo que sua destruição representaria um processo natural de extinção (ANDERSON, 2008: 6-28).

A ameaça Zulu ficava representada, por exemplo, na ilustração de Greiffenhagen para o desfecho da trama, no qual os escudos e as azagaias Zulus avançavam desordenadamente sobre Ralph e Suzanne (Figura 3), caracterizando-os portanto como um povo belicoso e periculoso e, por isso, passíveis de serem subjugados. Na óptica de muitos dos apologistas do 
colonialismo, o suposto caráter irracional das resistências armadas dos africanos constituía um impasse malogradamente fatal, sintomático do atavismo e incivilidade frequentemente atribuído às populações africanas. Tais narrativas integravam um conjunto maior de atitudes estruturantes das situações coloniais, isto é, a crença na "incapacidade dos indígenas de se gerir corretamente" e "o despotismo dos chefes tradicionais" (BALANDIER, 2014: 38). Ademais, as resistências africanas geraram, entre parte da literatura e da historiografia colonial, uma tendência à generalização e categorização das sociedades africanas entre estados belicosos e populações pacíficas, que não ofereciam resistência (RANGER, 2010: 53).

Figura 3

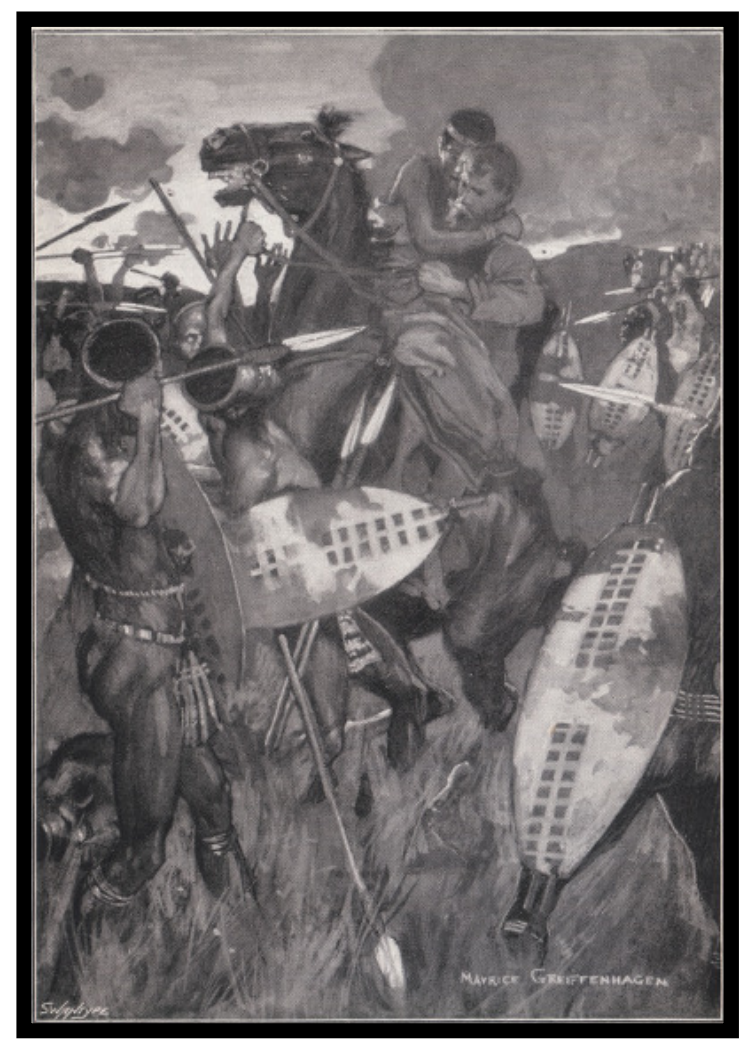

Fonte: Swallow, a tale of the Great Trek. Londres: Longman's Green \& Co, 1899, p.332.

As imagens em questão evidenciam rastros daquilo que Valentim Mudimbe designou de "biblioteca colonial", isto é, um conjunto de discursos constituídos no signo da alteridade, erigidos a partir do Ocidente em categorias 
etnocêntricas, que teriam interferido fortemente na compreensão das circunstâncias sociais concretas vivenciadas no continente, tanto dos atores externos quanto dos próprios africanos (MUDIMBE, 2013a: 12). Tratam-se, na perspectiva de Mudimbe, de "ideologias da alteridade" (MUDIMBE, 2013b: 117), de saberes sobre o outro embasados em concepções racistas amparadas na crença da suposta superioridade da cultura europeia ou Ocidental. Assim como demonstrou Paul Landau ao tratar das relações entre o uso de fotografias e a administração colonial na África, o desenvolvimento de códigos estéticos e de tecnologias de comunicação entre as colônias e as metrópoles possibilitou uma difusão mais eficaz da visualidade, comumente representando as populações na África enquanto exóticas, racialmente retrógradas ou mesmo em vias de extinção; ou, ainda, enquanto indivíduos anônimos e sem individualidade, representativos apenas de sua coletividade, de sua "tribo" ou "raça" (LANDAU, 2002). Devidamente desendividualizados, estas ficções literárias e políticas dificultavam a identificação ou a empatia dos leitores com determinados grupos étnico-sociais, em especial, no caso dos romances em questão, os africanos que resistiam à ocupação europeia na região.

Por outro lado, os ilustradores de Haggard também enfatizavam a violência descomedida por parte dos bôeres nas colônias, ao exemplo de Piet van Vooren que, na abertura do capítulo XL, "A fight and a shot", é apresentado por Hatherell prestes a castigar arbitrariamente um de seus lacaios negros (figura 4). Estas e outras representações imagéticas presentes em Swallow traziam para a esfera pública o domínio das sensibilidades, em particular a compaixão e a piedade que, outrora restritas ao cerne da intimidade, foram, ao longo do século XIX e na esteira da chamada "questão social", estruturantes de práticas políticas ligadas à solidariedade e à empatia com os mais "fracos" (ARENDT, 2011). Além do mais, reforçavam certos estereótipos associados aos bôeres sob o prisma britânico, representando-os como um povo que, devido à exposição prolongada às colônias, carecia de características civilizadas, dotados de atrofiamentos morais, preconceitos étnico-raciais e incompetência política, embora cercados por uma natureza que, para Haggard e 


\section{VISÕES DO IMPÉRIO: A VISUALIDADE DA ÁFRICA COLONIAL NA LITERATURA DE H. RIDER HAGGARD}

muitos dos seus contemporâneos, era compreendida como promissora, majestosa e exuberante. Estes estereótipos encontravam-se enraizados em princípios de degenerescência racial e declínio moral, e foram gradativamente reforçados entre a guerra de 1881, o Jameson Raid e a guerra de 1899-1902, com o intento de destacar o papel do colonizador britânico enquanto parte de uma raça sóbria e laboriosa, cujo caráter nacional havia conquistado o direito de governar outros povos ou "raças inferiores". Sobretudo na imaginação literária do período, o veredicto britânico reforçava duplamente a dimensão negativa sobre os bôeres, pois 1) tratavam-se de descendentes de europeus que haviam abandonado as supostas qualidades que os tornavam superiores e aptos a controlar terras e populações no sul da África; 2) a permanência prolongada na região resultara na incorporação da violência primitiva e de comportamentos selvagens comumente atribuídos na época aos africanos negros (LEE, 1999: 126).

Figura 4

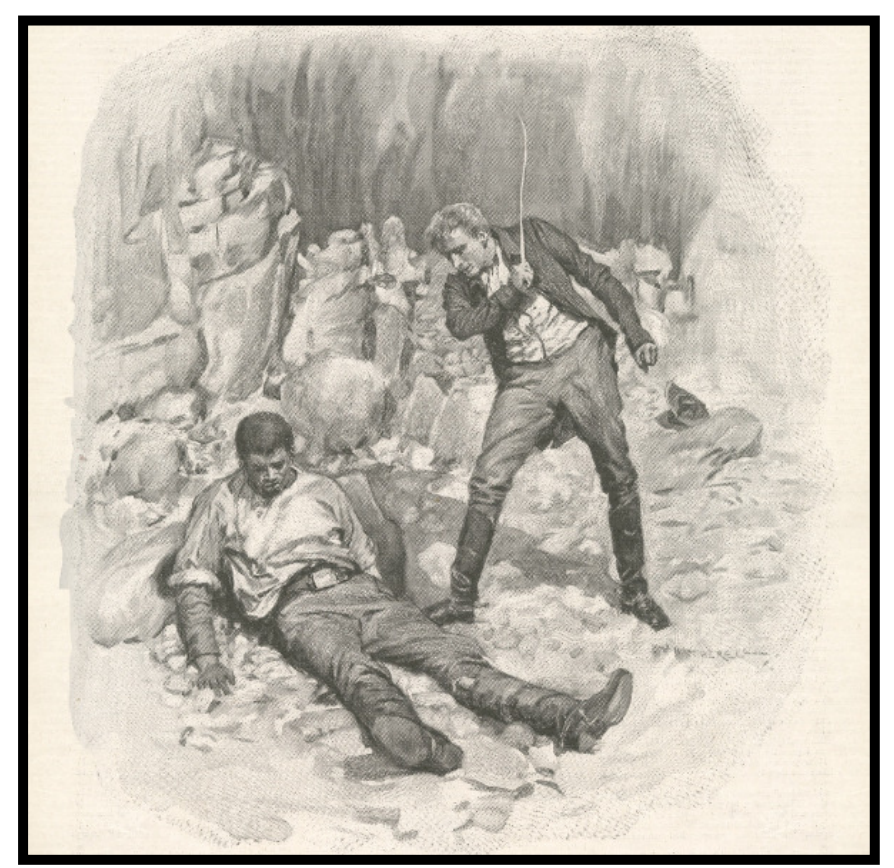

Fonte: Swallow, a tale of the Great Trek. The Graphic, 06 de agosto de 1898, p.201 
A imagem de Hatherell concatena referências visuais a padrões imagéticos presentes nas campanhas abolicionistas da primeira metade do século XIX, apresentando certa ausência de agência e ação por parte dos negros para enfatizar a crueldade dos castigos físicos associados às práticas servis, tanto na América quanto na África. A questão adquire relevância, afinal, um dos motivos alegados para a migração dos bôeres em meados de 1830 dizia respeito à proibição, por parte da administração britânica, do uso de mão de obra escrava em suas fazendas. Estas marcas da intericonicidade, as quais pressupõem "relações das imagens exteriores ao sujeito como quando uma imagem pode ser inscrita em uma série de imagens" (MILANEZ, 2004: 168169), podem ainda ser vislumbradas nas ilustrações de Greiffenhagen, incluídas na edição em volume único de Swallow. É o que se observa quando Gaasha, um prisioneiro dos Zulus e sobrevivente do conflito entre bôeres e Zulus, suplica por sua vida a Ralph Kenzie (figura 5). O posicionamento do corpo prostrado de Gaasha é profundamente reminiscente dos símbolos produzidos pela Society for Effecting the Abolition of the African Slave trade, instituída em Londres em 1787 (figura 6). O emblema, reiterado em panfletos, medalhas e escritos abolicionistas, com maiores ou menores alterações, possivelmente já era familiar aos leitores do romance, e sua apropriação pela ilustração de Greiffenhagen evidencia a reelaboração de fórmulas e esquemas de expressões imagéticas em contextos históricos distintos (HOLTERFOFF, 2013). 
Figuras 5 e 6

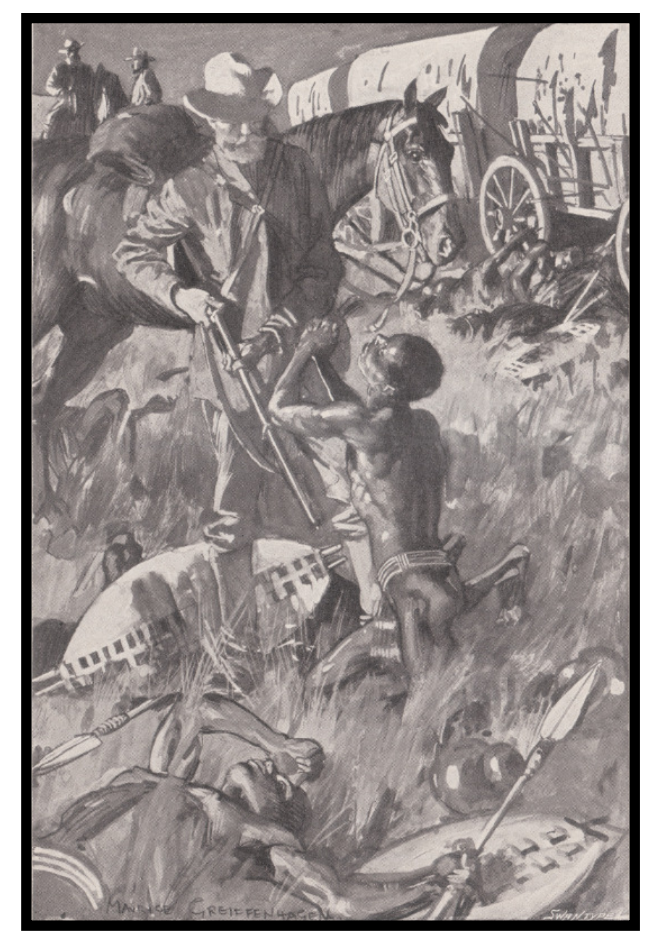

Fonte: Swallow, a Tale of the Great Trek. Londres: Longman's, Green \& Co, 1899: 245.

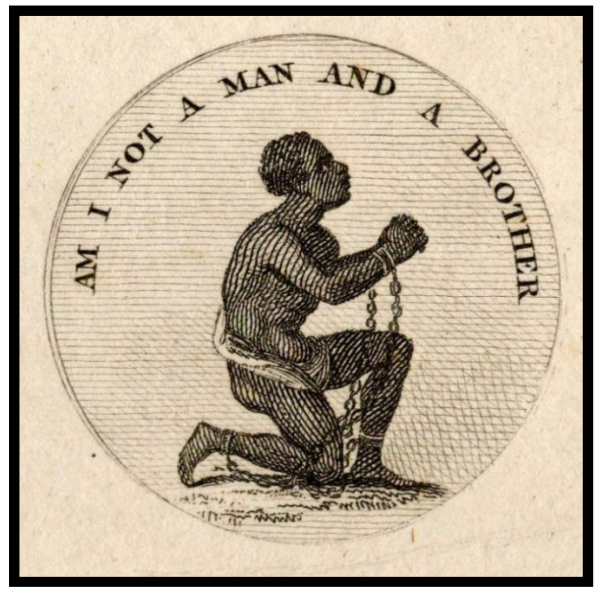

Fonte: Símbolo da Society for Effecting the Abolition of the African Slave trade (1787)

As interações entre texto e imagens presentes nas ilustrações que constituem os romances de Haggard possibilitam perceber as nuances dos entrecruzamentos entre códigos visuais e étnico-raciais na construção da visualidade da África colonial, entre o imaginário e a sensibilidade, sobretudo a compaixão e a empatia enquanto virtudes políticas (HUNT, 2009; BRESCIANI, 2012). O que se observa, nas gravuras de Greiffenhagen e Hatherell, é uma constante apropriação de elementos imagéticos presentes no campo das sensibilidades políticas, em especial, das representações relacionadas às campanhas abolicionistas, temática que não se enquadra necessariamente na narrativa textual de Haggard, o qual, embora situe sua trama no período imediatamente posterior ao Slavery Abolition Act de 1833, não enfatiza a questão. Em maior ou menor medida, a questão pode ainda ser vislumbrada em Hatherell, ao representar Suzanne salvando Sihamba das 
punições do cruel Piet van Vooren. Prostrada aos pés de seus algozes e amarrada com cordas ao tronco de uma árvore, a gravura alude a práticas de punição e violências físicas cometidas contra escravizados na América e na África, e difundidas na imprensa e panfletos abolicionistas pelo menos desde o início do século XIX (figuras 7 e 8). Ao retratarem as populações africanas, Hatherell e Greiffenhagen reiteram a ausência de agência nativa, representandoos como vítimas passivas da violência colonial ou meramente manipulados por homens como van Vooren. Ignora-se, assim, todo um contexto de resistências africanas ao avanço colonial, interpretando suas ações como movidas por certa tendência natural à violência racialmente condicionada.

\section{Figuras 7 e 8}

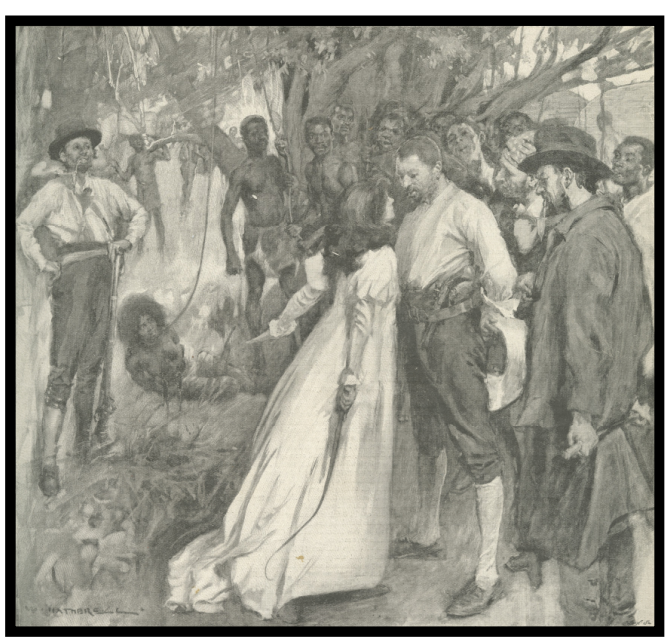

Fonte: Swallow, a tale of the Great Trek. The Graphic, 30 de julho de 1898 , p. 153.

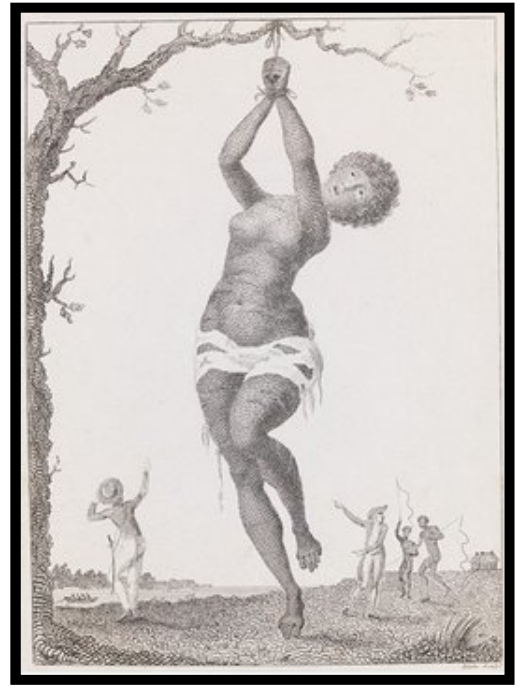

Fonte: William Blake. Flagellation of a Female Samboe Slave. Museu Victoria \& Albert. 1796.
A violência colonial é retomada por $\mathrm{A}$.
A. C. Michael, ilustrador responsável pela edição serializada e em volume único de The Ghost Kings. Neste romance, Haggard produziu uma trama que enfatiza as colônias na África do Sul enquanto espaços de revitalização da agency de mulheres brancas engajadas com a manutenção da presença europeia ultramarina. Ademais, o 
heroísmo feminino no romance colonial envolvia a passagem da infância à vida adulta em associação às forças da natureza, ao exemplo de tempestades e vendavais, reforçando uma imagem de feminilidade revigorada a partir das condições naturais das colônias. Contudo, o empoderamento de Rachel Dove, retratado no entrecruzamento de textos e imagens, visava reforçar a autoridade de indivíduos nascidos nas metrópoles sobre as populações africanas, em especial os Zulus. Assim, Haggard atribuía a Rachel qualidades tradicionalmente masculinas como força, calma e liderança, em especial ao afirmar que ela possuía por "coragem e força de caráter", além de ser "precavida (...), apreendendo as coisas com um estranho instinto" (HAGGARD, 1908: 9). Contudo, estas mesmas qualidades serviam a um propósito político: o heroísmo feminino como fulcro de identificação da autoridade colonial na África do Sul. A questão era reiterada em praticamente todas as imagens que retratavam as ações de Rachel no romance - por exemplo, sendo aclamada pelos Zulus pelos seus poderes sobrenaturais ou atuando como juíza ao julgar os crimes de Ishmael (figuras 9 e 10), de modo a reforçar qualidades atribuídas pelo literato à personagem. 
Figuras 9 e 10

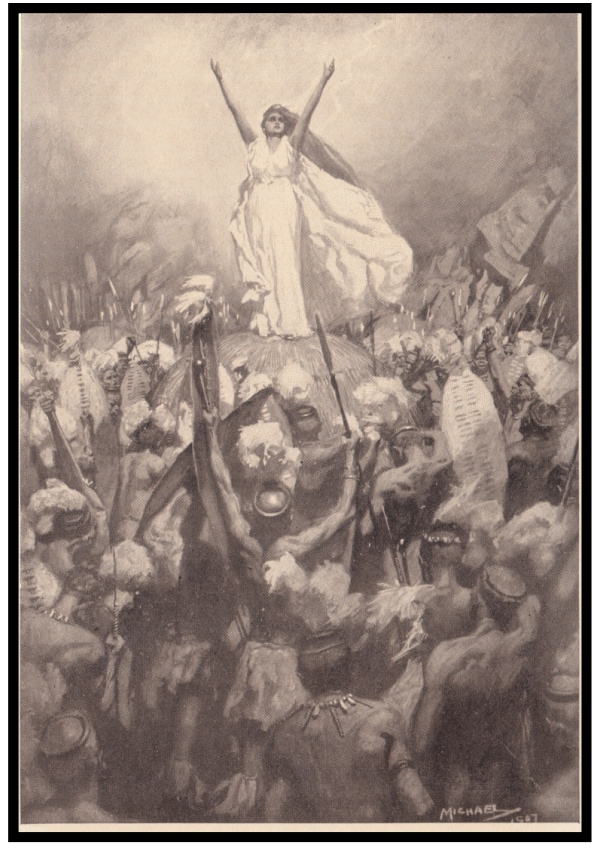

Fonte: The Ghost Kings. Londres: Cassel \& Co., 1908, p.244.

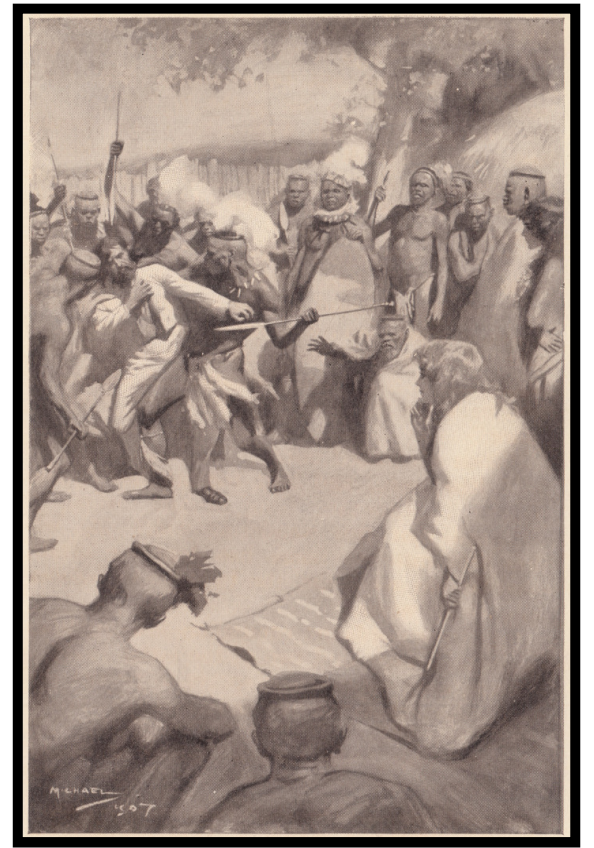

Fonte: The Ghost Kings. Londres: Cassel \& Co., 1908, p.150.

Finalmente, uma questão a ser denotada na visualidade da África colonial presente nos romances de Haggard, em especial em The Ghost Kings, diz respeito às representações imagéticas de africanos. Nas gravuras de A. C. Michael, persistia um contraste entre a brancura de Rachel e a negritude Zulu (figura 10). Estas imagens reforçavam estereótipos raciais estruturantes dos discursos coloniais do período em questão, os quais, como demonstrou Anne McClintock (2010, pp.307-340) associavam a sujeira e a feiúra enquanto características racialmente condicionadas, elementos reiterados em vasta produção visual do final do século XIX, como, por exemplo, nas propagandas de sabonetes e produtos de limpeza. A intericonicidade presente nestas imagens evidencia que, ao retratarem os negros africanos, os ilustradores de Haggard ancoravam-se não apenas em sua narrativa literária, mas também nos esquemas culturais de representação pictórica, noção que referencia a pré-existência de 
códigos visuais que determinam, com maior ou menor medida, as formas de figuração imagética (GOMBRICH, 2007).

Ao lado da questão racial, o ilustrador de The Ghost Kings apresenta o interior sul-africano enquanto dotado de uma natureza exuberante e exótica, mas simultaneamente incontrolável e inóspita, repleta de possibilidades de vivências aventurescas e arriscadas. Tome-se, a título de exemplo, as primeiras ilustrações do romance, que retratam um episódio na infância de Rachel e Richard, no qual os dois jovens ficam abrigados em uma caverna após uma enxurrada caudalosa causada por uma tempestade, a qual se abateu de forma "terrivelmente repentina e de fúria inconcebível (...), e por alguns minutos a escuridão tornou-se tão densa que ela [Rachel] mal conseguia cambalear adiante" (HAGGARD, 1908: 15). Diversos outros animais ficam igualmente presos entre as rochas, ao exemplo de leões e antílopes, os quais integravam os imaginários das caçadas e safáris que mobilizavam diversos europeus rumo ao interior da África (Figura 11). Destarte, o interior sul-africano era apresentado como uma região pouco explorada, e que, presumivelmente, oferecia vastas oportunidades econômicas à metrópole. A cena que retratava o dilúvio sulafricano (Figura 12) reforçava a ideia do protagonismo europeu diante das forças incontroláveis da natureza africana, e ilustrava o protótipo de herói e heroína que pulula nos romances aventurescos, dotados de "energia e vigor infatigável" aos quais "lhe são permitidas aventuras em que suas experiências lhes revelam os limites daquilo a que podem aspirar, aonde podem ir, o que podem vir a ser" (SAID, 2011: 130).

As representações da natureza sul-africana nas imagens que acompanhavam o romance de Haggard conjugavam um vasto leque de sensibilidades, ao exemplo da resignação e da submissão do indivíduo perante a grandiosidade do espaço natural, unindo elementos estéticos de caráter romântico, tais como o sublime e o pitoresco. Tais figurações dos territórios coloniais assumiam um papel central na literatura aventuresca produzida no período, a qual definia o "espaço da aventura" como distante, ausente de quaisquer traços de civilização, exótico e desconhecido; simultaneamente, 
tratavam-se de regiões perigosas, espaços nos quais o sentimento de risco mortal, essencial nos discursos sobre a aventura, concretizava-se (VENAYRE, 2001). Assim, em romances aventurescos como The Ghost Kings, a natureza sul-africana era apresentada como sendo simultaneamente majestosa, sublime e periculosa: tempestades sobrenaturais, dilúvios e rios caudalosos, animais selvagens pululam ao longo da trama. Finalmente, estas imagens desempenhavam um papel político, no sentido de que "o conhecimento da natureza" constituía um "elemento importante e primordial como explicação, justificação e legitimação do poder que se estabelece sobre as regiões consideradas e representadas como atrasadas, selvagens e bárbaras" (NAXARA, 2004: 68). Portanto, estas representações do território não eram frívolas e tampouco inofensivas, pois intencionavam a legitimação pública da conquista colonial, concatenando o entusiasmo de seus leitores ao apresentar a natureza sul-africana como indomável e desconhecida - um lugar propício para vivências aventurosas.

Figuras 11 e 12
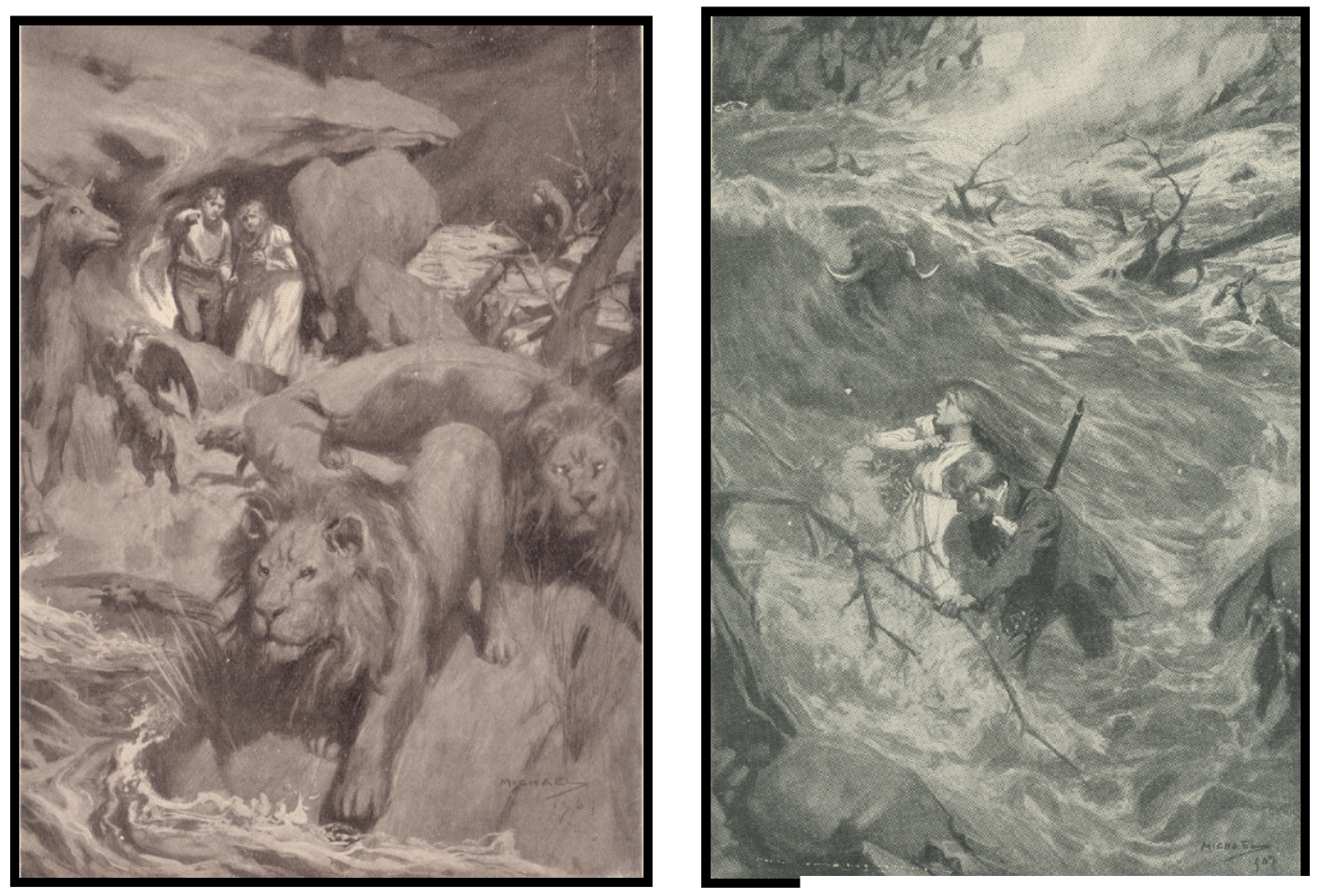

Fonte: The Ghost Kings. Londres: Cassel \& Co., 1908, p. 24

Fonte: The Ghost Kings, Pearson's Magazine, vol. 24-23, n. 142, 1907, p.341. 


\section{Considerações Finais}

Os romances aventurescos, que se tornaram verdadeiros best sellings nas últimas décadas do século XIX, foram responsáveis pela produção e circulação de diversos estereótipos associados à África colonial e aos homens e mulheres africanas, descritos, com certa frequência, a partir de uma lógica racial que estruturava as estratégias de dominação colonial a partir de paradigmas de inclusão e exclusão. Estas ficções literárias, publicadas em volume único ou em formato folhetinesco, encontravam-se comumente acompanhadas de gravuras e ilustrações que, em diálogo com a narrativa escrita, tornavam-se responsáveis pela legitimação pública de imaginários em torno da expansão colonial e dos seus articulistas, dos territórios a serem conquistados e das chamadas "raças inferiores". As violências derivadas do colonialismo legaram cicatrizes inegáveis ao continente africano, e a problematização histórica da produção literária e imagética da segunda metade do século XIX possibilita investigar os processos de engajamento afetivo do público leitor na metrópole com as políticas coloniais.

Desta forma, uma possibilidade de análise das expressões gráficas inerentes à produção literária está relacionada à visualidade, em especial, pela incorporação de imagens e ilustrações que integravam as narrativas ficcionais, afinal, "deve-se reconhecer e compreender o elemento plástico-pictural da criação artística verbal" (BAKHTIN, 2003: 86). As imagens de Hatherell, Greiffenhagen e Michael, publicadas nos romances Swallow e The Ghost Kings, apresentavam o território sul-africano da década de 1830 como uma região contestada pelos embates entre bôeres e africanos, sobretudo os Zulus, simultaneamente associando a benevolência e a ação justa a personagens associados ao colonialismo britânico. Muitas destas imagens eram amparadas em preceitos racistas, retratando as populações africanas como periculosas e violentas, destituídas de individualidade, ou, por outro lado, como vítimas da violência perpetrada pelos bôeres e passíveis da tutela paternal do colonialismo britânico, frequentemente retratado nestas produções como justo e benevolente. 
O arcabouço imagético que constituía os romances aventurescos e sentimentais de H. Rider Haggard desempenhavam importante papel na construção de uma imaginação literária e visual de seus leitores e leitoras a respeito dos territórios coloniais no extremo sul da África. Nas imagens analisadas, as colônias sul-africanas são vistas como territórios em que as ações de agentes coloniais chocam-se e entrecruzam-se à presença africana, frequentemente retratada a partir de estereótipos raciais. Simultaneamente às imagens de incivilidade, que categorizavam os negros africanos como "raças inferiores" e destituídas de capacidade de ação e agenciamento, os ilustradores de Haggard evocavam a intericonicidade - as referências a imagens do abolicionismo - para retratar a violência e culpabilizar os bôeres por práticas violenta no contexto dos embates coloniais.

\section{Referências}

ABREU, M. História dos textos, história dos livros e das práticas culturais. In: CHARTIER, R. Formas e sentido - cultura escrita: entre distinção e apropriação. Campinas: Mercado de Letras, 2003.

ANDERSON, C. Red Coats and Black Shields: Race and Masculinity in British Representations of the Anglo-Zulu War. Critical Survey, Nova Iorque, v. 20, n. 3, p. 6-28, 2008.

ANSART, P. A gestão das paixões políticas. Curitiba: UFPR, 2019.

ARBEX, M. Intertextualidade e intericonicidade. In: ARBEX, M.; OLIVEIRA, L.C.V. (org.). I Colóquio de Semiótica. Belo Horizonte: UFMG, 2003.

ARENDT, H. Sobre a revolução. São Paulo: Companhia das Letras, 2011.

BACZKO, B. A imaginação social. In: LEACH, E. (org). Anthropos-Homem. Lisboa: Imprensa Nacional/Casa da Moeda, 1985.

BAKHTIN, M. Estética da criação verbal. São Paulo: Martins Fontes, 2003.

BALANDIER, G. A situação colonial: abordagem teórica. Cadernos CERU, São Paulo, v. 25, n.1, pp. 33-58, 2014.

BRANTLINGER, P. Victorians and Africans: The Genealogy of the Myth of the Dark Continent. Critical Inquiry, Chicago, v. 12, n. 1, p.166-203, 1985. 
BRESCIANI, M. S. A compaixão na política como virtude republicana. In: BREPOHL, M.; CAPRARO, A. M.; GARRAFONI, R. S. (orgs.). Sentimentos na história: linguagens práticas, emoções. Curitiba: UFPR, 2012.

CHARTIER, R. Textos, impressão, leituras. In: HUNT, L. (org.). A Nova História Cultural. São Paulo: Martins Fontes, 1992.

CLARK, S. Regeneration of Empire: Agrarian Vision and Philantropic Colonisation in H. Rider Haggard's Novels. Dissertação (Mestrado), Victoria University, School of English, Film, Theatre and Media Studies. Wellington, 2017.

CLARKE, C. Late Victorian Crime Fiction in the Shadows of Sherlock. Basingstoke: Palgrave Macmillan, 2014.

CURRAN, A. The Anatomy of Blackness: Science and Slavery in an Age of Enlightenment. Nova York: Johns Hopkins University, 2013.

ETHERINGTON, N. The Great Treks: The Transformation of Southern Africa (1815-1854). Londres: Routledge, 2013.

GOMBRICH, E. Arte e ilusão: um estudo da psicologia da representação pictórica. São Paulo: Martins Fontes, 2007.

HAGGARD, H. R. The Ghost Kings. Londres: Cassel and Company, 1908.

HAGGARD, H. R. Swallow, a tale of the Great Trek. Nova York: Longmans, Green and Co., 1899.

HOBSBAWM, E. A era dos impérios, 1875-1914. Rio de Janeiro: Paz \& Terra, 2014.

HOLTERFOFF, K. Ethics and the Digital Archive: The Case for Visualizing H. Rider Haggard. Disponível em <http://jvc.oup.com/2013/10/21/ethics-andthe-digital-archive-the-case-for-visualizing-h-rider-haggard/>. Acesso em 19/01/2019.

HUNT, L. A invenção dos direitos humanos: uma história. São Paulo: Companhia das Letras, 2009.

LABAND, J. Historical Dictionary of the Zulu Wars. Lanham: Scarecrow Press, 2009.

LANDAU, P. Empires of the Visual: Photography and Colonial Administration in Africa. In: LANDAU, P. S.; KASPIN, D. D. (orgs.) Images and Empires: Visuality in Colonial and Postcolonial Africa. Berkeley: University of California Press, 2002. 
LEE, T. The Fiction of Difference: The Afrikaner in British Adventure Fiction. UCLA Historical Journal, Los Angeles, v. 18, n. 1, p.1-26, 1999.

MARTINS, A. P. V. Bondade, substantivo feminino: esboço para uma história da benevolência e da feminilização da bondade. História: Questões \& Debates, Curitiba, v. 59, n. 2, p.143-170, jul.-dez. 2013.

MCCLINTOCK, A. Couro Imperial: raça, gênero e sexualidade no embate colonial. Campinas: UNICAMP, 2010.

MILANEZ, N. A disciplinaridade dos corpos: o sentido em revista. In: SARGENTINI, V.; NAVARRO, P. (orgs.). M. Foucault e os domínios da linguagem: discurso, poder, subjetividade. São Carlos: Claraluz, 2004.

MUDIMBE, V. Y. A invenção da África: gnose, filosofia e a ordem do conhecimento. Lisboa: Mangualde, 2013.

MUDIMBE, V. Y. A idéia de África. Lisboa: Mangualde, 2013

NAXARA, M. R. C. Cientificismo e sensibilidade romântica. Brasília: UNB, 2004.

RANGEL, T. Iniciativas e resistências africanas em face da partilha e da conquista. In: BOAHEN, A. A. (org.). História Geral da África: África sob dominação colonial, 1880-1935. Brasília: UNESCO, 2010.

RICHARDS, J. (org.). Imperialism and Juvenile Literature. Manchester: Manchester University Press, 1987.

RICHNER, E. J. The historiographical development of the concept 'mfecane' and the writing of Early Southern African History, from the 1820s to 1920s. Dissertação (Mestrado), Rhodes University. Grahamstown, 2005 .

SAID, E. Cultura e imperialismo. São Paulo: Companhia das Letras, 2011.

SCHREUDER, D. The Imperial Historian as Colonial Nationalist: George McCall Theal and the Making of South African History. In: MARTEL, G. (org.). Studies in British Imperial History. Nova York: Palgrave Macmillan, 1986.

SILVA, E. R. da. H. Rider Haggard, imaginação literária e sensibilidade política: Jess (1887) e a perda do Transvaal (África do Sul). Fênix: Revista de História e Estudos Culturais, Uberlândia, v. 15, n. 1, p. 1-23, 2018.

STADLER, N. B. K. Em busca das colônias perdidas: a visualidade da propaganda do Movimento Neocolonial Alemão (1925-1943). Dissertação 
(Mestrado), Universidade Federal do Paraná, Programa de Pós-Graduação em História. Curitiba, 2015.

VENÂNCIO, G. M. A arte no tempo: por uma perspectiva sócio-cultural dos objetos artísticos. Fênix: Revista de História e Estudos Culturais, Uberlândia, v. 3, n. 4, p. 1-15, 2006.

VENAYRE, S. Une histoire des representations: l'aventure lointaine dans la France des annés 1850-1940. Cahiers d'histoire. Revue d'histoire critique, Paris, v. 84, n.1, p. 93-112, 2001.

Recebido em: 9 de maio de 2019 Aceito em: 03 de dezembro de 2019 